\title{
Regional Geologic Map of San Andreas and Related Faults in Carrizo Plain, Temblor, Caliente and La Panza Ranges and Vicinity, California: A Digital Database
}

Compiled by T. W. Dibblee ${ }^{1}$

Digital database prepared by S. E. Graham, T. M. Mahony, J. L. Blissenbach, J. J. Mariant, and C. M. Wentworth

\section{OPEN-FILE REPORT 99-14}

\section{9}

This report is preliminary and has not been reviewed for conformity with U.S. Geological Survey editorial standards or with the North American Stratigraphic Code. Any use of trade, product, or firm names is for descriptive purposes only and does not imply endorsement by the U.S. Government.

This database, identified as "Regional Geologic Map of San Andreas and Related Faults in Carrizo Plain, Temblor, Caliente and La Panza Ranges and Vicinity, California: A Digital Database," has been approved for release and publication by the Director of the USGS. Although this database has been subjected to rigorous review and is substantially complete, the USGS reserves the right to revise the data pursuant to further analysis and review. Furthermore, it is released on condition that neither the USGS nor the United States Government may be held liable for any damages resulting from its authorized or unauthorized use.

1316 Mission St., Santa Barbara, CA 93101

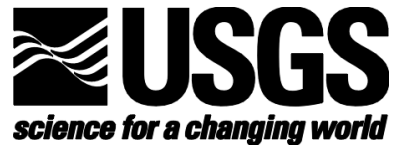


This Open-File Report is a digital geologic map database. The report serves to introduce and describe the digital data. There is no paper map included in the Open-File Report. The report includes PostScript and PDF plot files that can be used to plot images of the geologic map sheet and explanation sheet.

This digital map database is prepared from a previously published map by Dibblee (1973). The geologic map database delineates map units that are identified by general age, lithology, and clast size following the stratigraphic nomenclature of the U.S. Geological Survey. For descriptions of the units, their stratigraphic relations, and sources of geologic mapping, consult the explanation sheet (of99-14_4b.ps or of99-14_4d.pdf), or the original published paper map (Dibblee, 1973). The scale of the source map limits the spatial resolution (scale) of the database to $1: 125,000$ or smaller.

For those interested in the geology of Carrizo Plain and vicinity who do not use an ARC/INFO compatible Geographic Information System (GIS), but would like to obtain a paper map and explanation, PDF and PostScript plot files containing map images of the data in the digital database, as well as PostScript and PDF plot files of the explanation sheet and explanatory text, have been included in the database package (please see the section "Digital Plot Files", page 5). The PostScript plot files require a gzip utility to access them.

For those without computer capability, we can provide users with the PostScript or PDF files on tape that can be taken to a vendor for plotting. Paper plots can also be ordered directly from the USGS (please see the section " Obtaining Plots from USGS Open-File Services", page 5)

The content and character of the database, methods of obtaining it, and processes of extracting the map database from the tar (tape archive) file are described herein. The map database itself, consisting of six ARC/INFO coverages, can be obtained over the Internet or by magnetic tape copy as described below.

The database was compiled using ARC/INFO, a commercial Geographic Information System (Environmental Systems Research Institute, Redlands, California), with version 3.0 of the menu interface ALACARTE (Fitzgibbon and Wentworth, 1991, Fitzgibbon, 1991, Wentworth and Fitzgibbon, 1991). The ARC/INFO coverages are stored in uncompressed ARC export format (ARC/INFO version 7.x). All data files have been compressed, and may be uncompressed with gzip, which is available free of charge over the Internet via links from the USGS Public Domain Software page (http://edcwww.cr.usgs.gov/doc/edchome/ndcdb/public.html). ARC/INFO export files (files with the .e00 extension) can be converted into ARC/INFO coverages in ARC/INFO (see below) and can be read by some other Geographic Information Systems, such as MapInfo via ArcLink and ESRI's ArcView. 


\section{DATABASE CONTENTS}

The digital map database consists of digital files representing the seven ( 3 map coverages, 1 base coverage, 3 explanation coverages) parts of the database. The names of the files are unique designators based on the report identifier, of 99-14, followed by part numbers and an extension indicating file type. The larger files, which have been compressed with gzip, have .gz extensions as well.

1. Revision List

A list of the parts of the report and at what version number of the report each was last revised (if at all) followed by a chronologic list that describes any revisions:
a. of99-14revs1.txt
ASCII file

\section{Open File Text}

The text of the Open-Rile Report (this document), which describes the database and how to obtain it:
a. of 99-14_2a.txt
unformatted ASCII text
b. of99-14_2b.ps
c. of99-14_2c.pdf
PostScript file
PDF file

3. Geologic Map Database

The coverages, which are stored as uncompressed ARC/INFO export files compressed with gzip, are described below.

\begin{tabular}{|c|c|c|c|}
\hline $\begin{array}{l}\text { ARC/INFO } \\
\text { export file }\end{array}$ & $\begin{array}{l}\text { Size of gzip } \\
\text { compressed } \\
\text { export file } \\
\text { (uncompressed) }\end{array}$ & $\begin{array}{l}\text { Resultant } \\
\text { Coverage } \\
\text { (using } \\
\text { import.aml) }\end{array}$ & $\begin{array}{l}\text { Description of } \\
\text { Coverage }\end{array}$ \\
\hline of99-14_3a.e00 & $2.5 \mathrm{MB}(8.1 \mathrm{MB})$ & czo-geol & $\begin{array}{l}\text { Depositional contacts, faults and unit } \\
\text { labels }\end{array}$ \\
\hline of99-14_3b.e00 & $336 \mathrm{~K}(2.8 \mathrm{MB})$ & czo-strc & Fold axes, strike and dip information \\
\hline of99-14_3c.e00 & $47 \mathrm{~K}(168 \mathrm{~K})$ & czo-oil & Oil Fields \\
\hline of99-14_3d.e00 & $19.9 \mathrm{MB}(63 \mathrm{MB})$ & czo-topo & $\begin{array}{l}\text { Topographic base map taken from a } \\
\text { scan of a photomosaic of USGS } \\
15 \text { ' topographic quadrangles }\end{array}$ \\
\hline of99-14_3e.e00 & $60 \mathrm{~K}(120 \mathrm{~K})$ & czo-srcs & $\begin{array}{l}\text { Quadrangle index and sources of } \\
\text { geologic mapping }\end{array}$ \\
\hline of99-14_3f.e00 & $128 \mathrm{~K}(520 \mathrm{~K})$ & czo-strt & Generalized columnar sections \\
\hline of99-14_3g.e00 & $58 \mathrm{~K}(344 \mathrm{~K})$ & czo-corr & Correlation of map units \\
\hline of99-14_3h.tar & $23 \mathrm{MB}(75.3 \mathrm{MB})$ & & $\begin{array}{l}\text { Tar file containing all seven } \\
\text { coverages }\end{array}$ \\
\hline
\end{tabular}


ARC export files promote ease of data handling, and are usable by some other Geographic Information Systems in addition to ARC/INFO (see below for a discussion of working with export files).

4. PostScript and PDF plot files

The geologic map of the Carrizo Plain and accompanying explanation sheet (the PDF files are not compressed):

Plot file

of99-14_4a.ps

of $99-14 \_4 b . p s$

of99-14_4a.pdf

of 99-14_4b.pdf

\author{
Size of gzip \\ compressed \\ plot file \\ (uncompressed) \\ $15.1 \mathrm{MB}(54 \mathrm{MB})$ \\ $1.4 \mathrm{MB}(6 \mathrm{MB})$ \\ $10.8 \mathrm{MB}$ \\ $920 \mathrm{kB}$
}

Description of plot file

Carrizo Plain geologic map (PostScript)
Carrizo Plain explanation sheet (PostScript)
Carrizo Plain geologic map (PDF)
Carrizo Plain explanation sheet (PDF)

Carrizo Plain geologic map (PostScript)

Carrizo Plain explanation sheet (PostScript)

Carrizo Plain explanation sheet (PDF)

\section{OBTAINING PAPER MAPS FROM THE USGS}

NOTE: Plot-on-demand service should be available from the USGS in 1999.

The U.S. Geological Survey will make plots on demand from map files such as those described in this report.

Be sure to include with your request the Open-File Report number and the exact names, as listed in the Database Contents section above, of the plot file(s) you require. An Open-File Report number and its letter alone are not sufficient, unless you are requesting plots of all the plot files in this report. You may wish to determine the price before placing an order.

Order plots from:

USGS Information Services

Box 25286

Denver Federal Center

Denver, CO 80225-0046

(303) 202-4200

FAX: (303) 202-4695

e-mail: infoservices@usgs.gov 


\title{
DIGITAL PLOT FILES
}

For those interested only in the map or explanation images, who don't use an ARC/INFO compatible GIS system, but would like to obtain paper maps, we have included separate PostScript and PDF plot files.

The plot files are available in any of the three ways described below, including the World Wide Web pages. The PostScript plot files have been compressed with gzip and they must be uncompressed before use. The gzip utility is available free of charge over the Internet via links from the USGS Public Domain Software page:

\section{http://edcwww.cr.usgs.gov/doc/edchome/ndcdb/public.html}

The geologic map image is 35 inches wide by 58 inches long, and the explanation sheet is 34 inches wide by 38 inches long, so they require a large plotter to produce paper copies at the intended scale.

\section{OBTAINING THE GEOLOGIC MAP DATABASE OR DIGITAL PLOT FILES}

The PostScript and PDF plot files can be obtained in any of three ways:

1. Send a tape with request

Geologic map data file(s) and/or plot file (s) can be obtained by sending a tape with request to:

\author{
Carrizo Plain Map Database and/or Plot File \\ c/o Database Coordinator \\ U.S. Geological Survey \\ 345 Middlefield Road, MS 975 \\ Menlo Park, CA 94025
}

The file (s) will be returned on the tape. The acceptable tape types are:

$$
4.3 \text { or } 5.0 \mathrm{~GB}, 8 \mathrm{~mm} \text { Exabyte tape. }
$$

In the request be sure to include with your request the Open-File Report number and the exact names, as listed in the Database Contents section above, of the file(s) you require. An Open-File Report number and its letter alone are not sufficient, unless you are requesting all of the files for this report.

If you are obtaining a plot file on tape to give to a vendor to plot, make sure your vendor is capable of reading these tape types and PostScript and/or PDF plot files. 
2. Anonymous ftp over the Internet

To obtain files by ftp:

The files in these reports are stored on the U.S. Geological Survey Western Region FTP server. The Internet ftp address of this server is:

wrgis.wr.usgs.gov

Connect to this address directly using ftp or through a browser, log in with the user name 'anonymous', and enter your e-mail address as the password. This will give you access to all the publications available from the server wrgis.

The files in this report are stored in the subdirectory:

pub/open-file/of99-14

\section{From the Western Region Geologic Information Web Page}

The U.S. Geological Survey supports a set of graphical pages on the World Wide Web from which digital publications such as this one can be obtained. The web server for digital publications from the Western Region is "http://wrgis.wr.usgs.gov". Once at the main page, click on 'Geologic Map Databases' under the heading 'Data Online'; next click on 'California.' Scroll down to the link 'Open-File Report 99-14', which will take you to the web page for this report. Set your web browser to save to a local disk and click on the link for each desired file to download it.

\section{CONVERTING ARC EXPORT FILES}

ARC export files are converted to ARC coverages using the ARC command IMPORT with the option COVER. Change directories to the database directory. An import routine written in ARC MACRO LANGUAGE (AML) has been included to aid in the extraction of the coverages from the ARC export files. From the ARC command line type:

Arc: \&r import.aml

ARC export files can also be read by some other Geographic Information Systems. Please consult your GIS documentation to see if you can use ARC export files and the procedure to import them.

\section{DIGITAL COMPILATION}

The geologic map information was digitized from a paper copy of the original publication (Dibblee, 1973) at 1:125,000 scale. The map was traced on mylar using a drafting pencil. The mylar was scanned using a monochrome scanner with a resolution of 800 dots per inch. The scanned image was vectorized and transformed from scanner coordinates to State Plane 
projection coordinates with digital tics placed by hand at latitude/longitude intersections.

Transformation into real world coordinates was accomplished by cutting the vectorized scan into $15^{\prime}$ quadrangles. The 15' quadrangles were registered, and then reassembled once they had been projected. The scanned lines were edited interactively by hand using graphical user interface ALACARTE (Fitzgibbon, 1991, Fitzgibbon and Wentworth, 1991, Wentworth and Fitzgibbon, 1991). Scanning artifacts significant for display at a scale of $1: 125,000$ were corrected.

\section{BASE MAP}

The 1:125,000-scale topographic base map for the original 1973 published geologic map was specially prepared by mosaicking photographic reproductions of the index contours and selected cultural features of 7-1/2 minute topographic quadrangles (E. E. Brabb, oral communication, 1998). The result was a map that approximated a state-plane projection, especially for 15-minute blocks. A scale-stable clear film of the base was scanned using a monochrome scanner with a resolution of 400 dots per inch. The raster scan was converted to a GRID in ARC/INFO. The GRID was then vectorized and reprojected into State Plane Projection using the latitude/longitude intersections as reference points. Arcs in the digital base layer (czo-topo) are not attributed. The base map is provided for reference and plotting purposes.

\section{SPATIAL RESOLUTION}

Uses of this digital geologic map should not violate the spatial resolution of the data. Although the digital form of the data removes the constraint imposed by the scale of a paper map, the detail and accuracy inherent in map scale are also present in the digital data. The fact that this database was edited at a scale of 1:125,000 means that higher resolution information is not present in the dataset. Plotting at scales larger than 1:125,000 will not yield greater real detail, although it may reveal fine-scale irregularities below the intended resolution of the database. Similarly, where this database is used in combination with other data of higher resolution, the resolution of the combined output will be limited by the lower resolution of these data.

\section{FAULTS}

This database is not sufficiently detailed or comprehensive to identify or characterize sitespecific hazards represented by the faults shown; the faults shown do not distinguish active faults, nor do they take the place of fault-rupture hazard zones designated by the California Division of Mines and Geology (see, for example, Hart, 1988).

\section{DATABASE SPECIFICS}

The map databases consist of ARC coverages which are stored in State Plane projection (Table 
1). The explanation coverages (czo-srcs, czo-strt, czo-corr) have not been transformed into a coordinate system.

Table 1 - Map Projection

The map is stored in State Plane projection

PROJECTION UTM

UNITS METERS

ZONE 3376

DATUM NAD27

PARAMETERS -on the ground

-State Plane Zone 3376 (which is ARC/INFO's code for California State Plane coordinate system, zone 5

-none

The content of the geologic database can be described in terms of the lines and areas that compose it. Descriptions of the database fields use the terms explained in Table 2.

\section{Table 2 - Field Definition Terms}

ITEM NAME
WIDTH
OUTPUT
TYPE

N. DEC. name of the database field (item) maximum number of digits or characters stored output width

B-binary integer, F-binary floating point number, I-ASCII integer, C-ASCII character string number of decimal places maintained for floating point numbers

\section{LINES}

The lines (arcs) are recorded as strings of vectors and are described in the arc attribute table (Table 3). They define the boundaries of the map units, the faults, the boundaries of open bodies of water, and the map boundaries. These distinctions, including the geologic identities of the unit boundaries, are recorded in the LTYPE field according to the line types listed in Tables 4 and 5 . 
Table 3 - Content of the Arc Attribute Tables (CZO-GEOL.AAT, CZO-STRC.AAT, CZO

OIL.AAT)

ITEM NAME WIDTH OUTPUT TYPE N. DEC

\begin{tabular}{|c|c|c|c|c|c|}
\hline FNODE\# & 4 & 5 & B & & starting node of arc (from node) \\
\hline TNODE\# & 4 & 5 & B & & ending node of arc (to node) \\
\hline LPOLY\# & 4 & 5 & B & & polygon to the left of the arc \\
\hline RPOLY\# & 4 & 5 & B & & polygon to the right of the arc \\
\hline LENGTH & 4 & 12 & $\mathrm{~F}$ & 3 & length of arc in meters \\
\hline$<$ coverage $>\#$ & 4 & 5 & B & & unique internal control number \\
\hline$<$ coverage $>$-ID & 4 & 5 & B & & unique identification number \\
\hline LTYPE & 35 & 35 & $\mathrm{C}$ & & line type (see Tables 4 and 5) \\
\hline SEL & 1 & 1 & I & & $\begin{array}{l}\text { user defined field used to save a } \\
\text { selected set }\end{array}$ \\
\hline SYMB & 3 & 3 & I & & $\begin{array}{l}\text { user defined field used to save } \\
\text { symbol assignments (such as colo }\end{array}$ \\
\hline
\end{tabular}

Table 4 - Line Types Recorded in the LTYPE Field in CZO-GEOL
contact, approx. located
contact, certain
fault, approx. located
fault, certain
fault, concealed
map boundary, certain
scratch boundary, certain
thrust fault, certain
thrust fault, concealed

Table 5 - Line Types Recorded in the LTYPE Field in CZO-STRC

f.a., anticline, approx. located

f.a., anticline, certain

f.a., anticline, concealed

f.a., syncline, approx. located

f.a., syncline, certain

f.a., syncline, concealed 


\section{AREAS}

Map units (polygons) are described in the polygon attribute table (Table 6). The identities of the map units from compilation sources are recorded in the PTYPE field by map label (Tables 7 and 8). For a description of the map units, consult the PostScript or PDF explanation plot file (czoexpl.ps or czo-expl.pdf).

Table 6 - Content of the Polygon Attribute Tables (CZO -GEOL.PAT, CZO-OIL.PAT)

ITEM NAME WIDTH OUTPUT TYPE N. DEC

\begin{tabular}{|c|c|c|c|c|}
\hline AREA & 4 & 12 & $\mathrm{~F}$ & area of polygon in square meters \\
\hline PERIMETER & 4 & 12 & $\mathrm{~F}$ & length of perimeter in meters \\
\hline$<$ coverage $>\#$ & 4 & 5 & $\mathrm{~B}$ & unique internal control number \\
\hline$<$ coverage $>$-ID & 4 & 5 & $\mathrm{~B}$ & unique identification number \\
\hline PTYPE & 35 & 35 & $\mathrm{C}$ & unit label (see Tables 7 and 8) \\
\hline SEL & 1 & 1 & $\mathrm{I}$ & $\begin{array}{l}\text { user defined field used to save } \\
\text { a selected set }\end{array}$ \\
\hline SYMB & 3 & 3 & I & $\begin{array}{l}\text { user defined field used to save } \\
\text { symbol assignments (such as color }\end{array}$ \\
\hline
\end{tabular}

Table 7 - Map Units in CZO-GEOL

(listed alphabetically)

$\begin{array}{lllll}\text { Kcg } & \text { Ta } & \text { Tml } & \text { Tsm? } & \text { Tvs } \\ \text { Kco } & \text { Tb } & \text { Tmo } & \text { Tss } & \text { Tw } \\ \text { Kcr } & \text { Tbs } & \text { Tmo? } & \text { Ttb } \\ \text { Kh } & \text { Tbw } & \text { Tmp } & \text { Ttc } \\ \text { Kp } & \text { Tc } & \text { Tms } & \text { Ttg } & \text { f } \\ \text { Kpg } & \text { Tcg } & \text { Tmu } & \text { Ttm } & \text { gb } \\ \text { Kps } & \text { Te } & \text { Tmw } & \text { Ttn } \\ \text { Ks } & \text { Teb } & \text { Tpb } & \text { Ttr } & \text { gf } \\ \text { Kss } & \text { Tk } & \text { Tpe } & \text { Tts } \\ \text { QTp } & \text { Tkg } & \text { Tpr } & \text { Tts? } \\ \text { QTp? } & \text { Tkw } & \text { Tpr? } & \text { Ttu } & \text { gr } \\ \text { QTt } & \text { Tl } & \text { Tq } & \text { Tu } \\ \text { QTt? } & \text { Tm } & \text { Trr } & \text { Tus } & \text { jo } \\ \text { Qtu } & \text { Tma } & \text { Tsc } & \text { Tva } & \text { sp } \\ \text { Qa } & \text { Tmb } & \text { Tsg } & \text { Tvc } & \\ \text { Qaa } & \text { Tmd } & \text { Tsi } & \text { Tvl } & \\ \text { Qc } & \text { Tmi } & \text { Tsj } & \text { Tvp } & \\ \text { Qls } & & \text { Tsm } & \text { Tvq } & \end{array}$




\section{Table 8 - Map Units (CZO-OIL) \\ oilfield}

\section{POINTS}

Point information (strikes and dips) is recorded as coordinate and related information and is described in the Point Attribute Table (Table 9). The identities of point types recorded in the PTTYPE field of the SC-STRC.PAT table are listed in Table 10.

Table 9 - Content of the Point Attribute Tables in CZO-STRC.PAT

ITEM NAME WIDTH OUTPUT TYPE N. DEC

\begin{tabular}{|c|c|c|c|c|c|}
\hline AREA & 4 & 12 & $\mathrm{~F}$ & 3 & not used \\
\hline PERIMETER & 4 & 12 & $\mathrm{~F}$ & 3 & not used \\
\hline$<$ coverage $>\#$ & 4 & 5 & B & & unique internal control number \\
\hline$<$ coverage $>$-ID & 4 & 5 & $\mathrm{~B}$ & & unique identification number \\
\hline PTTYPE & 35 & 35 & $\mathrm{C}$ & & point type (see Table 10) \\
\hline DIP & 3 & 3 & I & & dip angle in degrees \\
\hline STRIKE & 3 & 3 & I & & strike angle in degrees \\
\hline SEL & 1 & 1 & I & & $\begin{array}{l}\text { user defined field used to } \\
\text { save a selected set }\end{array}$ \\
\hline SYMB & 3 & 3 & $\mathrm{I}$ & & $\begin{array}{l}\text { user defined field used to } \\
\text { save symbol assignments } \\
\text { (such as color) }\end{array}$ \\
\hline DIPQUERY & 1 & 1 & $\mathrm{I}$ & & $\begin{array}{l}\text { set to } 1 \text { if dip is queried and } 0 \\
\text { if it is not }\end{array}$ \\
\hline
\end{tabular}

Dip values that are set to -99 represent those structures that did not have a dip associated with them on the original published map (Dibblee, 1973). Horizontal beds have a dip of 0 .

Table 10 - Point Types (CZO-STRC)

bedding

flat bedding

foliation

horz bedding

ot bedding

vert bedding 


\section{REFERENCES CITED}

Dibblee, T. W., 1973, Regional geologic map of San Andreas and related faults in Carrizo Plain, Temblor, Caliente, and La Panza Ranges and vicinity, California, U. S. Geologica Survey Misc. Geol. Inv. Map I-757, scale 1:125,000.

Fitzgibbon, T.T., 1991, ALACARTE installation and system manual (version 1.0): U.S. Geological Survey, Open-File Report 91-587B.

Fitzgibbon, T.T., and Wentworth, C.M., 1991, ALACARTE user interface - AML code and demonstration maps (version 1.0): U.S. Geological Survey, Open-File Report 91-587A.

Hart, E.W., 1988, Fault-rupture hazard zones in California; Alquist-Priolo Special Studies Zones Act of 1972 with index to special studies zones maps: California Division of Mines and Geology Special Publication 42.

Wentworth, C. M., and Fitzgibbon, T. T., 1991, ALACARTE user manual (version 1.0): U. S. Geological Survey Open-File Report 91-587C. 